\title{
VEE DIAGRAM DIPADU CONCEPT MAP SEBAGAI ALAT KONSEPTUAL UNTUK MENGEMBANGKANPEMAHAMAN KONSEP MAHASISWA
}

\author{
Handayani $^{1)}$ \\ ${ }^{1}$ Program Studi Pendidikan Biologi FKIP, Universitas Kuningan \\ Email: handa_yani08@yahoo.co.id
}

APA Citation: Handayani. (2017). Vee Diagram Dipadu Concept Map Sebagai Alat Konseptual Untuk Mengembangkanpemahaman Konsep Mahasiswa. Quagga: Jurnal Pendidikan dan Biologi, 9(2), 7-11. doi: 10.25134/quagga.v9i02.942.

\begin{abstract}
Abstrak: Penelitian ini bertujuan untuk mengetahui penerapan Vee Diagram dipadu Concept Map dalam mengembangkan pemahaman konsep mahasiswa. Penelitian ini dilakukan pada mahasiswa semester V Tahun Akademik 2016/ 2017 sebanyak 1 kelas yang dikelompokkan menjadi 6 kelompok dan dilakukan selama 4 tahap menggunakan alat konseptual Vee diagram dan Concept map. Tahap pertama merupakan tahap pengenalan Vee Diagram dan Concept Map serta dilakukan penilaian pemahaman konsep awal mahasiswa pada materi fisiologi tumbuhan. Tahap kedua hingga tahap keempat setiap kelompok mahasiswa menerapkan Vee Diagram dan Concept Map pada tiap tahapnya, diakhir setiap tahapan dilakukan penilaian untuk mengetahui sejauh mana pemahaman konsep. Teknik pengumpulan data menggunakan tes yang digunakan untuk mengukur pemahaman konsep mahasiswa sebelum penerapan dan diakhir setiap tahapan. Lembar observasi disertai rubrik digunakan untuk menilai Vee Diagram dan Concept Map yang dibuat oleh mahasiswa. Hasil penelitian diperoleh peningkatan pemahaman konsep mahasiswa dari tahap pertama hingga tahap keempat.
\end{abstract}

Kata kunci: Vee Diagram, Concept Map, Pemahaman Konsep

\begin{abstract}
This study aims to determine the application of Vee Diagram combined Concept Map in developing students' conceptual understanding. This research was conducted in the first semester of $2016 \mathrm{~V} 2017$ Academic Year as many as 1 class which was grouped into 6 groups and carried out for 4 stages using Vee diagram conceptual tools and Concept maps. The first stage is the introduction stage of the Vee Diagram and Concept Map as well as an assessment of the understanding of students' initial concepts on plant physiology material. The second stage to the fourth stage of each student group applies the Vee Diagram and Concept Map at each stage, at the end of each stage an assessment is carried out to determine the extent of understanding the concept. Data collection techniques use tests that are used to measure students' understanding of concepts before application and at the end of each stage. The observation sheet along with the rubric is used to assess the Vee Diagram and Concept Map made by students. The results of the study obtained an increase in the understanding of student concepts from the first to the fourth stage.
\end{abstract}

Keywords: Vee Diagram, Concept Map, Concept Understanding

\section{PENDAHULUAN}

Sains merupakan pengetahuan yang diperoleh melalui serangkaian proses yang dilakukan secara sistematis oleh manusia dalam menjelaskan tentang alam. Sains dipandang sebagai produk dimana didalamnya berkaitan denganfakta-fakta, hukum-hukum, dan teori-teori yang sudah diterima kebenarannya. Pembelajaran sains sebagai produk diselenggarakan dengan tujuan agar peserta didik memahami dan menguasai konsep-konsep, prinsip-prinsip, dan teori-teori sebagai dasar untuk menguasai produk sains yang lebih kompleks. Sains sebagai produk ini tentunya tidak terlepas dari aspek lain pada sains yaitu proses dan sikap. Sains dipandang sebagai proses dimana didalamnya terdapat kegiatan penyelidikan untuk mencari kebenaran atau pengetahuan melalui proses ilmiah yang mana proses tersebut merupakan bagian dari keterampilan proses sains. Sains dipandang sebagai sikap, merupakan pembelajaran sains yang bertujuan menumbuhkan dan mengembangkan sikap ilmiah seperti rasa ingin tahu, teliti, kerja keras, dan sikap lainnya yang mendorong seorang ilmuwan untuk melakukan penyelidikan ilmiah. Oleh karena itu, aspek proses dan sikap dalam sains merupakan komponen penting dalam rangka memahami konsep agar dapat menguasai produk sains yang lebih kompleks. Hal ini berlaku dalam proses pembelajaran baik di tingkat sekolah maupun universitas.

Banyak cara yang dapat dilakukan di tingkat universitas dalam rangka mempelajari sebuah 
konsep. Tetapi yang paling penting adalah bagaimana hal ini dilakukan dan metode atau teknik apa yang digunakan oleh dosen untuk mempermudah mahasiswa dalam memahami konsep. Saat ini banyak metode atau teknik pembelajaran yang digunakan untuk membantu proses pembelajaran menjadi lebih bermakna. Suasana yang sesuai harus dipersiapkan untuk mempersiapkan mahasiswa dalam hal merancang penelitian serta berbagi informasi dan mendiskusikannya. Mahasiswa tidak boleh meniru apa yang diberikan oleh dosen tetapi dalam mempelajari konsep mahasiswa diharapkan dapat mempertimbangkan pengetahuan, pengalaman dan pendapat mereka sendiri dalam membangun konsep.

Salah satu cara yang efektif diantara caracara lainnya untuk mengakomodir pembelajaran bermakna adalah dengan menerapkan Vee Diagram dan Concept Map secara bersamasama. Penggunaan Vee Diagram dan Concept Map secara bersama-sama bertujuan untuk memberikan pembelajaran bermakna tentang kaitan antara struktur dan fungsi tumbuhan. Concept Map merupakan skema yang digunakan untuk melihat sub konsep dari konsep dan hubungannya dalam tatanan hierarki. Dengan kata lain menunjukkan konsep yang terkait dari umum ke khusus dan terkait dengan hubungan antara konsep sebagai diagram (Gowin dan Novak, 1984). Vee Diagram merupakan struktur diagram yang terdiri dari sisi metodologi dan konseptual. Pada awalnya Vee Diagram digunakan untuk membantu kerja di laboratorium. Namun, karena sifatnya terbatas Vee Diagram dikembangkan untuk bentuk pembelajaran lainnya (Ozsoy, 2004).

1) Vee Diagram merupakan teknik pembelajaran yang menghubungkan antar konsep yang disajikan dalam bentuk diagram. Melalui Vee Diagram memudahkan mahasiswa dalam memahami struktur dan konstruksi pengetahuan melalui interaksi antara yang belum diketahui dengan yang sudah diketahui dalam penyelidikan ilmiah (Gowin dan Alvarez dalam Calais, 2009: Sementara Concept Map merupakan suatu bagan skematik yang menggambarkan pengertian konseptual dalam suatu rangkaian pernyataan dan menghubungkan antara konsep-konsep tersebut (Suparno 1997: 56). Concept Map dapat membantu menyatakan hubungan antara konsep-konsep melalui kata penghubung untuk meningkatkan arti bagi konsep. Oleh karena itu, penggunaan Vee
Diagram dan Concept Map diharapkan dapat membantu mahasiswa dalam mencapai konsep dan kaitan dengan konsep lainnya sehingga mudah memahami konsep-konsep. Sejalan dengan pendapat Polancos (2012) yang menyatakan bahwa baik Vee Diagram dan Concept Map membantu mahasiswa mengembangkan system konseptual dan pembelajarannya.

Berdasarkan uraian di atas maka dilakukan penelitian mengenai penerapan Vee Diagram dan Concept Map sebagai alat konseptual untuk mengembangkan pemahaman konsep mahasiswa

\section{METODOLOGI PENELITIAN}

Penelitian dilaksanakan di Program Studi Pendidikan Biologi Universitas Kuningan pada mahasiswa Semester V Tahun Akademik 2016/ 2017 sebanyak 1 kelas yang dikelompokkan menjadi 6 kelompok dan dilakukan selama 4 tahap menggunakan alat konseptual Vee Diagram dan Concept Map. Tahap pertama merupakan tahap pengenalan Vee Diagram dan Concept Map serta dilakukan penilaian pemahaman konsep awal mahasiswa pada materi fisiologi tumbuhan. Tahap kedua hingga tahap keempat setiap kelompok mahasiswa menerapkan Vee Diagram dan Concept Map pada tiap tahapnya, diakhir setiap tahapan dilakukan penilaian untuk mengetahui sejauh mana pemahaman konsep mahasiswa pada materi fisiologi tumbuhan. Pada setiap tahapan, tiap kelompok menerapkan Vee Diagram dan Concept Map dan mempresentasikan hasil Vee Diagram dan Concept Map yang dikritisi oleh kelompok lainnya.

Teknik pengumpulan data menggunakan tes yang digunakan untuk mengukur pemahaman konsep mahasiswa sebelum penerapan dan diakhir setiap tahapan. Lembar observasi disertai rubrik digunakan untuk menilai Vee Diagram dan Concept Map yang dibuat oleh mahasiswa.

\section{HASIL DAN PEMBAHASAN Data Vee Diagram}

Data Vee Diagram diperoleh dengan menggunakan lembar observasi disertai rubrik Vee Diagram milik Novak dan Gowin (1985). Penilaian dilakukan pada komponen-komponen yang terdapat pada Vee Diagram yaitu, fokus pertanyaan; objek atau kejadian; teori, prinsip dan konsep; transformasi data dan klaim pengetahuan. Diperoleh skor penilaian Vee 
Quagga: Jurnal Pendidikan dan Biologi

Volume 9, Nomor 2, Juli 2017

Diagram selama tiga tahap berturut-turut, dimulai dari tahap kedua hingga tahap keempat. Pada tahap pertama tidak dilakukan penilaian karena pada tahap ini merupakan tahap pengenalan Vee Diagram. Terjadi peningkatan skor Vee Diagram untuk setiap tahapan. Hasil penilaian Vee Diagram tersaji pada gambar 1 di bawah ini:



Gambar 1. Penilaian Vee Diagram

\section{Data Concept Map}

Data Concept Map diperoleh dengan menggunakan lembar observasi disertai rubrik Concept Map milik Novak dan Gowin (1985). Penilaian didasarkan pada komponen yang terdapat pada Concept Map yaitu banyaknya hubungan konsep, hierarki konsep, cross links antar konsep dan contoh konsep. Diperoleh skor penilaian Concept Map selama tiga tahap berturut-turut, dimulai dari tahap kedua hingga tahap keempat. Pada tahap pertama tidak dilakukan penilaian karena pada tahap ini merupakan tahap pengenalan Concept Map. Terjadi peningkatan skor Concept Map untuk setiap tahapan. Hasil penilaian Concept Map tersaji pada gambar 2 di bawah ini:

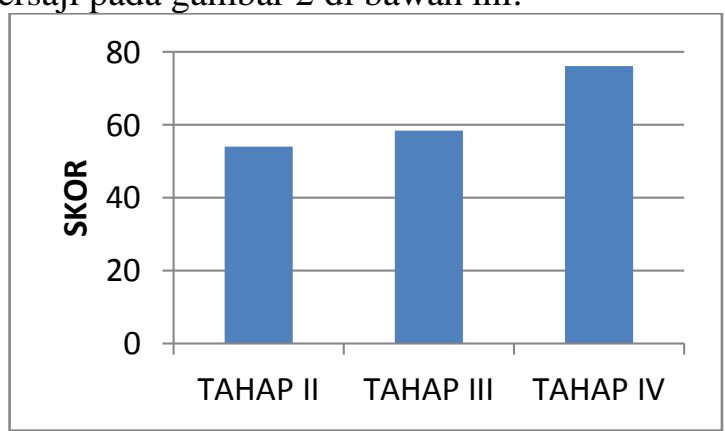

Gambar 2. Penilaian Concept Map

\section{Data Pemahaman Konsep}

Data pemahaman konsep diperoleh dari ratarata tes yang dilakukan diakhir setiap tahapan. Tes pemahaman konsep dilakukan pada setiap tahap setelah salah satu bab pada materi fisiologi tumbuhan selesai diajarkan. Terjadi peningkatan pemahaman konsep dari tahap pertama dimana mahasiswa baru diperkenalkan pada teknik Vee
p-ISSN 1907-3089, e-ISSN 2651-5869

https://journal.uniku.ac.id/index.php/quagga

Diagram dan Concept Map hingga pada tahap kedua, ketiga dan keempat setelah penerapan Vee Diagram dan Concept Map. Hasil pemahaman konsep mahasiswa sebelum dan setelah penerapan Vee Diagram dan Concept Map tersaji pada gambar 3 berikut ini:

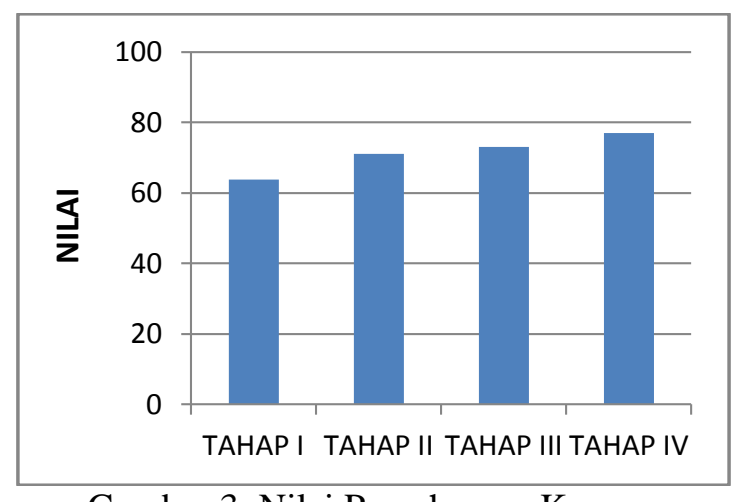

Gambar 3. Nilai Pemahaman Konsep

\section{Pembahasan}

Berdasarkan penilaian rubrik Vee Diagram dan Concept Map terjadi peningkatan skor hingga tahap keempat. Materi fisiologi tumbuhan merupakan materi yang berkaitan antara struktur dan fungsi, didalamnya terintegrasi berbagai materi seperti anatomi tumbuhan, morfologi tumbuhan, biokimia dan kimia. Hal ini menyebabkan antara konsep satu dengan yang lainnya memiliki keterkaitan yang luas sehingga mahasiswa akan lebih mudah memahami konsep apabila dalam pembelajaran menggunakan teknik pembelajaran Vee Diagram yang dipadu dengan Concept Map. Masing-masing alat konseptual ini mengungkapkan bahasa yang sama dengan cara yang berbeda. Vee Diagram menunjukkan struktur pengetahuan, sedangkan Concept Map adalah diagram kata yang menunjukkan hubungan gagasan. Vee Diagram dan Concept Map ditampilkan untuk menunjukkan bagaimana alat ini mempengaruhi konteks pembelajaran antara mahasiswa dengan dosen saat mempelajari informasi baru (Alvarez, 2005).

Pada saat penerapan Vee Diagram mahasiswa mengkaitkan antara sisi konseptual yang berisi teori, prinsip dan konsep dengan sisi metodologi yang dijabarkan dalam bentuk rancangan eksperimen. Pemaparan konsep pada sisi konseptual disajikan dalam bentuk Concept Map untuk mempermudah mahasiswa dalam melihat keterkaitan antara konsep satu dengan konsep lainnya. Pada awalnya mahasiswa kesulitan dalam menerapkan rancangan eksperimen dalam bentuk Vee Diagram. Pada sisi konseptual mahasiswa kesulitan dalam 
menjabarkan prinsip dan konsep dimana konsep dituangkan dalam bentuk Concept Map, pada sisi metodologi mahasiswa kesulitan dalam menentukan transformasi data dan klaim pengetahuan. Tetapi setelah tahap ketiga dan keempat, terjadi peningkatan dalam pembuatan Vee Diagram khususnya pada komponen prinsip dan konsep, transformasi data dan klaim pengetahuan. Konsep yang disajikan dalam bentuk Concept Map juga mengalami peningkatan yang terlihat dari banyaknya hubungan konsep, hierarki dan cross links antar konsep. Peningkatan dalam penerapan Vee Diagram dan Concept Map sejalan dengan peningkatan pemahaman konsep mahasiswa yang mulai nampak pada tahap kedua hingga tahap keempat. Hal ini menunjukkan bahwa penerapan Vee Diagram dan Concept Map membantu mahasiswa dalam mengembangkan pemahaman konsep. Sesuai dengan pendapat Polancos (2012) yang menyatakan bahwa Vee Diagram dan Concept Map membantu mahasiswa dalam mengembangkan sistem konseptual dan pembelajarannya. Keduanya mendorong mahasiswa dalam menggunakan konsep yang dimiliki dan membangun hubungan antar konsep dimana hubungan konseptual dapat membantu mahasiswa dalam menjelaskan secara teoritis tentang perubahan yang diamati. Menurut Passmore (1998) penggunaan Vee Diagram dan Concept Map dapat mengembangkan strategi berpikir metakognitif, mempelajari informasi secara bermakna, memahami struktur, hubungan dan hierarki konseptual sehingga mampu memberikan pembelajaran yang lebih bermakna. Hal ini nampak pada rata-rata pemahaman konsep mahasiswa yang mengalami peningkatan dari tahap kedua hingga tahap keempat.

Menurut Karoline dan Afamasaga (2004) melalui Vee Diagram mahasiswa mempelajari struktur konseptual dengan cara yang lebih bermakna mengenai materi yang dibahas dengan menggunakan metode dan prosedur yang relevan. Penggunaan Vee Diagram dapat memberikan pengetahuan yang mendalam tentang struktur konseptual sehingga memotivasi mahasiswa untuk belajar lebih lanjut tentang materi yang mereka pelajari, disamping itu Vee Diagram dapat menguraikan konsep yang ditunjukkan oleh Concept Map sehingga dapat memahami materi lebih baik. Teori Ausubel tentang belajar bermakna menjelaskan bahwa belajar bermakna terjadi melalui dua tahap, tahap pertama berupa penerimaan informasi oleh mahasiswa melalui penerimaan atau penemuan, dan tahap kedua berhubungan dengan mengaitkan informasi dengan struktur kognitif yang sudah ada (Dahar,1989). Pembelajaran melalui Vee Diagram membantu mahasiswa dalam menerima dan menemukan konsep sedangkan mengkaitkan antara konsep satu dengan konsep yang lainnya dibantu dengan penggunaan Concept Map.

Sisi konseptual dan sisi metodologi pada Vee Diagram membantu mahasiswa dalam merefleksikan proses belajar dan produk belajarnya di kelas. Teknik pembelajaran ini menekankan pada belajar bermakna dan ideal digunakan dalam struktur aktivitas kerja sama sesuai dengan teori Vygotsky yang menekankan belajar berkelompok. Pembelajaran melalui Vee Diagram membantu mahasiswa dalam learning how to learn (Novak dan Gowin, 1985). Mahasiswa lebih mudah memadukan sisi konseptual dengan metodologi dalam rangka merubah konseptual yang ada sehingga diperoleh konsepsi yang lebih baik dibandingkan dengan penerimaan pengetahuan ditunjukkan dengan berkembangnya pemahaman konsep (Hewson dan Hewson dalam Sujanem, 1998). Berkembangnya pemahaman konsep mahasiswa juga didukung kemampuan mahasiswa dalam mengorganisasi konsep yang telah dipelajari berdasarkan arti dan hubungan antar konsep sehingga memudahkan mahasiswa untuk memahami keterkaitan antara struktur dan fungsi pada materi fisiologi tumbuhan. Melalui Concept Map mahasiswa dapat mengintegrasikan secara jelas pengetahuan yang baru dengan yang lama.

Perkembangan Vee Diagram nampak dalam menentukan prinsip yang sesuai dengan fokus pertanyaan yang disajikan oleh mahasiswa. Pada awalnya prinsip yang disajikan mahasiswa pada sisi konseptual Vee Diagram tidak memiliki perbedaan dengan teori yang disajikan, namun pada tahap ketiga dan keempat mahasiswa sudah mampu dalam menentukan prinsip yang sesuai dengan fokus pertanyaan yang disajikan. Transformasi data yang disajikan mahasiswa berkembang dari hal yang membahas teori menjadi hal-hal yang berkaitan dengan proses dan hasil pelaksanaan praktikum. Klaim pengetahuan yang diajukan pada mulanya belum berkaitan dengan kebermanfaatan dalam kehidupan sehari-hari. Namun pada tahap terakhir sebagian besar kelompok sudah mampu menentukan klaim pengetahuan yang baik. Perkembangan Concept Map yang disajikan mahasiswa nampak pada hierarki konsep yang sesuai dan memiliki tingkatan hierarki yang lebih 
Quagga: Jurnal Pendidikan dan Biologi

Volume 9, Nomor 2, Juli 2017

banyak, hubungan antar konsep juga memiliki jaringan yang semakin luas dari Concept Map yang tersaji pada tahap kedua hingga tahap keempat, begitu pula dengan Cross links yang menunjukkan semakin banyak garis hubungan yang tersaji dalam Concept Map. Perkembangan ini menunjukkan perkembangan kognitif mahasiswa semakin terlatih. Menurut Piaget (dalam Suparno, 2001:88-89) perkembangan kognitif mahasiswa yang berada pada operasional formal, menjadikan mahasiswa mampu berpikir logis, berpikir dengan pemikiran teoretis formal berdasarkan proposisi-proposisi dan hipotesis, dan menyimpulkan berdasarkan apa yang diamati.

Vee Diagram dan Concept Map membantu mahasiswa dalam memahami konsep pada materi fisiologi tumbuhan yang dipelajari mahasiswa. Mahasiswa mampu menganalisis struktur konseptual dan mudah dalam mengembangkan berpikir deduktif dan induktif. Pembelajaran melalui Vee Diagram membantu dan memudahkan mahasiswa untuk mengintegrasikan konsep-konsep yang telah mereka ketahui sebelumnya dengan peristiwa yang mereka amati, mahasiswa terlibat aktif secara fisik dan mental untuk mengoptimalkan kemampuan yang dimiliki untuk menemukan sebuah konsep dari materi yang diajarkan. Proses belajar demikian memungkinkan mahasiswa memperoleh struktur konseptual dari kemampuan berpikir kritis dan bernalar dengan logika ilmiah yang dilakukan sendiri. Mahasiswa yang membentuk struktur konseptualnya sendiri memberikan kontribusi yang lebih baik terhadap prestasi belajar. Sementara itu pembelajaran melalui Concept Map mampu mengembangkan struktur kognitif yang terintegrasi dengan baik, yang akan memudahkan belajar. Disamping itu dapat membantu mahasiswa melihat makna materi pelajaran secara lebih komprehensif dalam setiap komponen konsep-konsep dan mengenali hubungan antara konsep-konsep berikut. Apabila mahasiswa tersebut mampu mencapai pemahaman relasional atau konseptual, maka ia mampu mengkonstruksi pengetahuan sendiri dan menghasilkan pembelajaran yang lebih bermakna, serta menghasilkan pemahaman konsep yang lebih baik (Novak dan Gowin, 1985)

\section{SIMPULAN}

Penerapan Vee Diagram yang dipadu dengan Concept Map dapat membantu mahasiswa dalam mengembangkan pemahaman konsep melalui
p-ISSN 1907-3089, e-ISSN 2651-5869

https://journal.uniku.ac.id/index.php/quagga

pengkaitan sisi konseptual dan sisi metodologi pada Vee Diagram, dimana Vee Diagram dapat menguraikan konsep yang ditunjukkan oleh Concept Map.

\section{REFERENSI}

Alvarez, Marino C. 2005. Conceptual Tools For Improving Self-Knowledge: V Diagrams, Concept Maps, and Time Writtings. Department of Teaching and Learning Teaching and Learning Presentation: Tennese State University.

Calais, Gerald J. (2009). The Vee Diagram as a Problem Solving Strategy: Conten Area Reading/Writing Implications. National Forum Teacher Education Journal. Department of Teacher Education Burton College of Education Mc.Neese State University, Lake Charles, Louisiana, 19(3): 1-8.

Dahar, R.W. (1989). Teori-teori Belajar. Jakarta: Erlangga.

Karoline and Afamasaga Fuata'i. (2004). Concept Map and Vee Diagram as Tools for learning New Mathematics Topics. Proc of the first Int. Conference on Concept Mapping.

Novak, J. D \& Gowin D. (1985). Learning How To Learn. Cambridge, MA: Cambridge University Press.

Ozsoy, Nerin. 2004. Using Concept Maps and Vee Diagrams as a Teaching and Learning Tool on The Unit The Function. Journal of GaziEducation Faculty, Vol 24(2): 15-24.

Passmore, G. (1998). Using Vee Diagram to Facilitate Meaningful Learning and Misconcepttion.Radiological Science and education, 4(1): 11-28.

Polancos, D. T. (2012). Effects of Vee Diagram and Concept Mapping on the Achievement of Students in Chemistry. Ched Acredited Research Journal. 7(1): 18-35.

Sujanem, Rai. (1998). Efektivitas Model Belajar Heuristik Vee dengan Peta Konsep dalam Pembelajaran Fisika di SMU. Jurnal Pendidikan dan Pengajaran, 3(1): 46-56.

Suparno, Paul. (1997). Filsafat Konstruktivisme dalam Pendidikan. Yogyakarta: Kanisius.

Suparno, Paul. (2001). Teori Perkembangan Kognitif Jean Piaget. Yogyakarta: Kanisius. 